\title{
THE IMPACT OF MERGERS AND ACQUISITIONS ON FINANCIAL PERFORMANCE OF LISTED COMPANIES IN CHINA
}

\author{
Chen Yadong ${ }^{1}$ \\ School of Management, Universiti Sains Malaysia, Malaysia. \\ (Email: usmyadongchen@gmail.com) \\ Lok Char Lee ${ }^{2}$ \\ School of Management, Universiti Sains Malaysia, Malaysia. \\ (Email: lokcl@usm.my) \\ Phua Lian Kee $\mathrm{Ke}^{3}$ \\ School of Management, Universiti Sains Malaysia, Malaysia. \\ (Email: phualk@usm.my) \\ Kenny Quah ${ }^{4}$ \\ School of Management, Universiti Sains Malaysia, Malaysia. \\ (Email: kenny_quah@hotmail.com)
}

Received date: 22-09-2019

Revised date: 03-11-2019

Accepted date: 05-11-2019

Published date: 12-12-2019

To cite this document: Chen, Y., Lok, C. L., Phua, L. K., \& Quah, K. (2019). The Impact of Mergers and Acquisitions on Financial Performance of Listed Companies in China. International Journal of Entrepreneurship and Management Practices, 2 (8), 01-12.

DOI: $10.35631 /$ ijemp.28001

\begin{abstract}
The purpose of this paper is tantamount to study whether mergers and acquisitions $(M \& A)$ improve the financial performance of Chinese listed companies. We use panel data regression to examine 434 completed M\&A activities from 2012 to 2016 initiated by Chinese companies listed on the Shanghai and Shenzhen Stock Exchanges. The evidence indicates that, on average, the firm performed better after the M\&A activities. We further divide all sample enterprises into three different types of $M \& A$. The results demonstrate that when other conditions are unchanged, horizontal $M \& A$ and conglomerate $M \& A$ are positively related to firm performance. Our results suggest that the firm can benefit from horizontal M\&A through economies of scale in operations while financial synergies following the conglomerate $M \& A$ enhance the firm performance. The findings deepen our understanding of the consequences of $M \& A$ and provide evidence that it is an important corporate growth strategy for the Chinese capital market.
\end{abstract}

Keywords: Types Of M\&A, Financial Performance, China, Panel Data

\section{Introduction}

According to Bhabra and Huang (2013), mergers and acquisitions (M\&A) contribute to the efficient allocation of resources in an economy. M\&A activities serve as an external governance mechanism to reconfigure allocation of resources among enterprises. According 
to National Statistics in 2008, China's economy was the most prominent among high-growth, international economic entities in terms of its involvement in M\&A deals. Compared to 2007 in which China's M\&A activities set a record, the M\&A volume reached US\$167 billion in 2008. A survey conducted by $\mathrm{Hu}$ (2018) indicates that China's business investors continue to have high M\&A demands and China will continue to be the top choice for the majority of Chinese companies to conduct the M\&A activities. M\&A may affect the firm performance directly and the shareholder wealth indirectly. However, the extant literature is unable to provide answers on whether M\&A create value for enterprises and improve firm performance as a result of the theoretical synergy effect and economies of scale of larger operations.

This study revisits the impacts of M\&A on firm performance. In order to deepen the understanding regarding the financial impact of these activities, we further examine the models according to three types of M\&A. The findings contribute to the corporate governance theories and also explain how different types of M\&A might affect firm performance while controlling other firm and corporate governance characteristics.

This paper provides unique research value by using the sample firms of Chinese stock market. China is a typical emerging market that, compared with western markets, is characterized by poor corporate governance, serious government intervention, and agency problems, which lead to poor corporate performance and high operational risk ( $\mathrm{Fu}, \mathrm{Xiong}, \mathrm{Li}, \& \mathrm{Chesbrough}$, 2014).

There are various classification methods for corporate M\&A, and the type of M\&A depends directly on the classification criteria. According to the industry relationship of the participating companies, M\&A could be classified into horizontal, vertical and conglomerate. While the horizontal merger is merger between two firms in direct competition which share the same product lines and markets, the vertical merger is between a supplier and a customer in the same supply chain. On the other hand, conglomerate merger is between two companies that have no common business areas, tantamount to the diversification strategy.

The samples in this study are selected from the Chinese listed firms from the year 2012 to 2016. The sample firms include both domestic and cross-border acquisitions. We measure the accounting-based financial performance to make a scientific and reasonable evaluation of the firm performance of the acquirer enterprises before and after the merger.

\section{Literature Review and Hypothesis Development}

Scholars have made a large number of theoretical and empirical analyses on M\&A. Most of the relevant studies focus on the changes in corporate performance and shareholder wealth following the M\&A activities. As for the research on the changes of shareholder wealth, scholars pay close attention to the extraordinary returns of the stocks of M\&A firms in a period before or after the announcement date of M\&A events. In the prior studies conducted by Dodd and Ruback (1977), Asquith, Bruner, and Mullins (1983), Schwert (1996), Mei and Sun (2008), Liargovas and Repousis (2011), and Bhabra and Huang (2013), the cumulative abnormal return is used to measure the firm performance after the M\&A and they found that M\&A can create wealth for the shareholders of the acquiring company. However, the findings of Leeth et al. (2000), Chen and Young (2010) and Rahim and Pok (2013) on abnormal returns, indicate that the M\&A affects the shareholder wealth negatively.

In addition to the cumulative abnormal return, accounting-based financial indicators are also used to measure the firm performance after M\&A. Kelly (1968) found that the price-earnings 
ratio of merging companies is higher than non-merging companies. Similarly, Healy, Palepu and Ruback (1990), and Ghosh (2001) discovered that M\&A lead to higher operating cash flow returns for the firm. On the other hand, Yeh \& Hoshino (2002) found that M\&A are detrimental to profitability, sales growth rate, and the workforce. Fraser and Zhang (2009) comparing the adjusted return on assets (ROA) and return on equity (ROE) of listed companies, the results show that these financial ratios improved significantly within three years after M\&A.

Several studies have been conducted on the impact of different types of M\&A on firm performance. Han Kim and Singal (1993) observed that horizontal mergers are conducive to improving enterprise performance, generating some form of synergy, realizing optimal allocation of resources, and enhancing social benefits. Fee and Thomas (2004) investigated large sample firms from the year 1980 to 1997 and found improved production efficiency and buying power of firms after horizontal mergers. Similarly, Bhattacharyya and Nain (2011) found that horizontal mergers create better buying power and impact the performance of dependent suppliers. Fan and Goyal (2006) found that vertical mergers can produce positive wealth effects, and their performance is not much different from horizontal mergers, but it is significantly better than conglomerate mergers. However P. Chen, Xu and Zou (2017) found that a vertical merger leads to a drop in the total profit of the supply chain. Elgers and Clark (2010) found that compared to non-conglomerate mergers, conglomerate mergers showed superior wealth effects for both buyer and seller shareholder. Wansley, Lane and Yang (2012) research on 203 mergers and acquisitions in the US market from 1970 to 1978, documented that during the 40 days prior, the abnormal return rate of conglomerate mergers samples was higher than that of horizontal mergers and vertical mergers samples, and abnormal return is significantly positive.

Due to the obvious difference in development stage and efficiency between Chinese capital market and British and American capital market because Chinese stock market has not reached the weak-form market efficiency. In other words, the fluctuation of stock prices does not reflect the real operating performance of the company very well, as a result, most scholars adopt the accounting based measures for China's M\&A events. Changqi and Ningling (2010) examined the cross-border M\&A activities of the Chinese listed companies, it was reported that the proportion of the state-owned shares has a positive impact on the performance of acquiring companies. Similarly, G. Chen, Firth and Xu (2009) studied the M\&A with dissimilar ownership structure, the empirical results indicate that the operating efficiency of firms varies across the type of controlling shareholder. In short, the empirical results of M\&A studies are still inconsistent based on both accounting-based performance as well as the firm value.

In the 1960s, American strategic management scientist Igor Ansoff (1985) introduced the concept of synergy into the field of corporate management. A group of scholars represented by Jensen and Ruback (1983) believes that the main objective for M\&A is to obtain synergies. Synergy can be divided into three types: management synergy, operation synergy and financial synergy. Management synergy refers to the transfer of management capabilities between enterprises after mergers, which is mainly reflected in the improvement of enterprise management efficiency. The operation synergy is embodied economies of scale, vertical integration effect, market power and complementary resources. Financial synergy refers to the improvement of the financial ability, expected effects and the reasonable tax avoidance brought by mergers and acquisitions. Therefore, rooted in the synergistic effect, this paper proposes the following hypothesis: 
Hypothesis 1: Generally, M\&A can improve corporate performance.

The transaction cost theory was proposed by Nobel Prize-winning economist Coase (1934), argue that the cost of certain inputs in the market can be reduced by establishing an indefinite, semi-permanent hierarchical relationship, or by combining resources to form an organization like a company. Similarly, vertical merger connects producers with sellers or sellers with buyers, which enables coordination between supplier and customer to remove the transaction costs in the market. Through the vertical merger, enterprises can realize vertical integration, which is conducive to strengthening the control of the whole process of raw material supply, product manufacturing, distribution and sales, enabling enterprises to take the initiative in the market competition, to increase the profits in each stage of business activities. Based on the transaction cost theory, this paper proposes the following hypothesis:

Hypothesis 2: Vertical mergers can improve corporate performance.

The theory of economies of scale motivates the intention to engage in horizontal mergers. It is argued that horizontal merger can reduce production cost and depreciation expense and hence, achieve economies of scale for the firm (Mueller, 2012). George J. Stigler (2009) believes that a small number of companies occupy a large market share in an industry. Once a merger is made, it is easy to lead to collusion to obtain monopoly profits. Consistent with the theory of economies of scale, this paper proposes the following hypothesis:

Hypothesis 3: Horizontal merger can improve corporate performance.

Firms choose to diversify when the benefits of diversification outweigh the costs of diversification. In the conglomerate, two merger parties are belonging to different industries with relatively different financial structures and the marginal efficiency of capital. As a result, internal capital optimization can be conveniently realized and hence, able to reduce the cost of capital and financial risks. Moreover, Conglomerate mergers can complement the advantages of firms within the same group of companies. In a conglomerate, resources can be allocated more effectively and capital can flow from projects with lower marginal returns to projects with higher marginal rates (Mueller, 1967). In contrast, Va and Ofekb (1995) and Lang and Stulz (1994) found that diversified firms trade at a discount relative to non-diversified firms in their industries. Other findings also confirm the existence of this discount on diversified firms, and this result seems to be robust to different periods and different countries (Kruse, Park, Park, \& Suzuki, 2007; Servaes, 1996). There is a growing consensus that the discount on diversified firms implies destruction of value on account of diversification, that is, on account of firms operating in multiple divisions. Therefore, conglomerate mergers may lead to diversification discounts.. Jensen and Meckling (1976) reported that due to the differences in the information held by different interest groups and the existence of incomplete contracts, agency conflicts are caused.

Roll (1986) proposed he hubris hypothesis in 1986, the theory holds that in a strong and efficient market, the company's market value has basically reflected its value, but the management of the acquirer will overestimate the target company and conduct mergers and acquisitions because of arrogance and blind optimism, lead to the income of the acquirer is negative. Based on potential costs of agency theory and hubris hypothesis as well as the benefits of synergy effects, this paper proposes the following hypothesis: 
Hypothesis 4: Conglomerate mergers can affect corporate performance positively or negatively.

\section{Methodology}

Based on the current situation of China's stock market, the fluctuation of stock price is more influenced by manipulation and public policy changes, and the change of stock price may not represent the change of shareholders' value over all. Therefore, we use accounting information informant instead in this study. The research method of this paper (panel data and fixed effect model) is also consistent with Changqi and Ningling (2010), Marfo, Samuel, and Agyei (2013).

The sample firms of this study are Chinese listed firms which involved in M\&A activities between 2012 and 2016. The data comes from the wind database, which sampled 434 listed Chinese companies. In this study, the annual financial statements of the above 434 listed companies from 2011 to 2016 will be collected from Sina financial database.

The firm performance measurements used in academic studies of M\&A activities include stock market indicators and operational performance. Return on Assets (ROA) and Return on Equity (ROE) are main operational performance measurements, which reflect changes in corporate profit as a result of M\&A activities. This study adopts ROA as firm performance indicator (Garcia-castro, Arin, \& Canela, 2010) while the variable of interest is M\&A event and the control variables include cross-border merger, firm size of acquirer, state ownership of acquirer, the independent board of acquirer and cash holding of acquirer. We further examine the effect of horizontal merger, vertical merger and conglomerate merger on firm performance.

The model that has been developed is as follows:

Model 1:

$$
\begin{aligned}
\text { ROA }_{i, t}=\alpha+ & \beta_{1} \text { Merger }_{i, t}+\theta_{1} \text { Fsize }_{i, t}+\theta_{2} \text { Inter }_{i, t}+\theta_{3} \text { Buyerstatues }_{i, t} \\
& +\theta_{5} \text { ind_board }_{i, t}+\theta_{6} \text { cash_ratio }_{i, t}+\varepsilon
\end{aligned}
$$

Model2:

$$
\begin{gathered}
{\text { ROA } A_{i, t}=\alpha+}_{\beta_{1} \text { Ver_merger }_{i, t}+\theta_{1} \text { Fsize }_{i, t}+\theta_{2} \text { Inter }_{i, t}+\theta_{3} \text { Buyerstatues }_{i, t}} \\
+\theta_{5} \text { ind_board }_{i, t}+\theta_{6} \text { cash_ratio }_{i, t}+\varepsilon
\end{gathered}
$$

Model 3:

$$
\begin{gathered}
\text { ROA }_{i, t}=\alpha+\beta_{1} \text { Hori_merger }_{i, t}+\theta_{1} \text { Fsize }_{i, t}+\theta_{2} \text { Inter }_{i, t}+\theta_{3} \text { Buyerstatues }_{i, t} \\
+\theta_{5} \text { ind_board }_{i, t}+\theta_{6} \text { cash_ratio }_{i, t}+\varepsilon
\end{gathered}
$$

Model 4:

$$
\begin{gathered}
{\text { ROA } A_{i, t}=\alpha+} \beta_{1} \text { Conglo_merger }_{i, t}+\theta_{1} \text { Fsize }_{i, t}+\theta_{2} \text { Inter }_{i, t}+\theta_{3} \text { Buyerstatues }_{i, t} \\
+\theta_{5} \text { ind_board }_{i, t}+\theta_{6} \text { cash_ratio }_{i, t}+\varepsilon
\end{gathered}
$$

where $\mathrm{t}$ indexes years, $\mathrm{i}$ indexes firms and $\varepsilon$ is an error term. 
The definitions of all the variables, including the experimental and control variables follow:

$\begin{array}{ll}\text { ROA } & \begin{array}{l}\text { Return on Assets is measured as the ratio of net profit after tax to } \\ \text { total assets of Firm i in time t }\end{array} \\ \text { Merger } & \text { Dummy variable of } 1 \text { for post-merger, otherwise } 0 \\ \text { Ver_merger } & \text { Dummy variable of } 1 \text { for vertical merger, otherwise } 0 \\ \text { Hori_merger } & \text { Dummy variable of } 1 \text { for horizontal merger, otherwise } 0 \\ \text { Conglo_merger } & \text { Dummy variable of } 1 \text { for conglomerate merger, otherwise } 0 \\ \text { Fsize } & \text { Firm size is the natural logarithm of total assets } \\ \text { Inter } & \text { Dummy variable of } 1 \text { for merger with a foreign firm, otherwise } 0 \\ \text { Buyerstatues } & \text { Dummy variable of } 1 \text { when the acquirer is a state-owned } \\ & \text { enterprise, otherwise } 0 \\ \text { Ind_board } & \text { Independent board is the ratio of independent directors divided } \\ & \text { by total number of board members } \\ \text { Cash } & \text { Cash holding is measured as the ratio of cash to total assets }\end{array}$

\section{Findings of The Study}

Table 1 shows the summary of the descriptive statistics for the variables used in this research. The data cover a range of years from 2012 to 2016 based on the Chinese listed firms. The mean of the Return on Assets (ROA) of sample firms is 0.045 with the minimum value of 0.375 and maximum value is 0.590 . The variable for merger (MERGER) shows that $37.30 \%$ of firms are post-acquisition M\&A within the period of study. The M\&A is then further broken down into vertical merger (VER_MERGER), horizontal merger (HORI_MERGER) and conglomerate merger (CONGLO_MERGER). The horizontal merger is the most popular merger with a mean of 0.255 while only $3.9 \%$ of M\&A are vertical merger. The mean for the foreign merger (INTER) indicates that $8.10 \%$ of M\&A involved foreign firms. As for the acquirer status, $10.8 \%$ of them are state-owned (BUYERSTATUES). The ratio of independent directors (IND_BOARD) indicates that $38.50 \%$ of board members are performing supervisory role. On average, $21.3 \%$ of total assets are held in cash (CASH_RATIO).

Table 1: Descriptive Statistics

\begin{tabular}{lcccc}
\hline Variable & Minimum & Maximum & Mean & $\begin{array}{c}\text { Standard } \\
\text { Deviation }\end{array}$ \\
\hline ROA & -0.375 & 0.590 & 0.045 & 0.057 \\
MERGER & 0 & 1 & 0.373 & 0.484 \\
VER_MERGER & 0 & 1 & 0.039 & 0.193 \\
HORI_MERGER & 0 & 1 & 0.255 & 0.436 \\
CONGLO_MERGER & 0 & 1 & 0.076 & 0.266 \\
FSIZE & 4.888 & 8.700 & 6.436 & 0.530 \\
INTER & 0 & 1 & 0.081 & 0.272
\end{tabular}




\begin{tabular}{lcccc} 
BUYERSTATUES & 0 & 1 & 0.108 & 0.311 \\
IND_BOARD & 0.2 & 0.6 & 0.385 & 0.054 \\
CASH_RATIO & 0.002 & 2.608 & 0.213 & 0.163 \\
\hline
\end{tabular}

Source: Wind Data Base

The Pearson Correlation for this research is tabulated in Table 2 which consists of the dependent variable, independent variable and control variables. The results show that the highest correlation between the variable is general merger firms (MERGER) and horizontal types of merger (HORI_MERGER) with 0.760 . The result is obviously due to $25.5 \%$ of M\&A activities involved companies within the competitors in the same industry, i.e. horizontal of merger. Thus, these two variables are highly correlated since the horizontal merger is a subset of the merger of the dataset. 
Table 2: Pearson Correlation

\begin{tabular}{|c|c|c|c|c|c|c|c|c|c|c|c|}
\hline & Variable & 1 & 2 & 3 & 4 & 5 & 6 & 7 & 8 & 9 & 10 \\
\hline 1 & ROA & 1 & & & & & & & & & \\
\hline 2 & MERGER & -0.025 & 1 & & & & & & & & \\
\hline 3 & HORI_MERGER & -0.003 & $0.760 * *$ & 1 & & & & & & & \\
\hline 4 & VER_MERGER & -0.037 & 0.261 & -0.118 & 1 & & & & & & \\
\hline 5 & CONGLO_MERGER & -0.013 & $0.373 * *$ & $-0.169 * *$ & $-0.058 * *$ & 1 & & & & & \\
\hline 6 & FSIZE & $-0.178 * *$ & $0.443 * *$ & $0.369 * *$ & $0.082 * *$ & $0.140 * *$ & 1 & & & & \\
\hline 7 & INTER & -0.034 & -0.013 & 0.017 & -0.001 & $-0.048 * *$ & $0.068 * *$ & 1 & & & \\
\hline 8 & BUYERSTATUES & $-0.061 * *$ & 0.030 & 0.034 & $0.058 * *$ & $-0.040 *$ & $0.246 * *$ & -0.022 & 1 & & \\
\hline 9 & IND_BOARD & $0.039 *$ & 0.023 & 0.011 & -0.011 & 0.027 & $-0.093 * *$ & 0.024 & $-0.079 * *$ & 1 & \\
\hline 10 & CASH_RATIO & $0.276^{* *}$ & $-0.241 * *$ & $-0.181 * *$ & $-0.060 * *$ & $-0.098 * *$ & $-0.326 * *$ & $0.014 * *$ & $-0.063 * *$ & $0.058 * *$ & 1 \\
\hline
\end{tabular}


Model 1 of the Table 3 shows the regression results of general merger (MERGER) and control variables on firm performance. It is reported that firms performed better after general merger. The results also indicate that higher cash ratio is related to better ROA. However, larger firms perform poorer than smaller firms. As reported in the Model 2 of the Table 4, we replace the independent variable with the vertical merger (VER_MERGER). The results show that vertical merger is not significant to firm performance. Keeping all variables unchanged, the results of Model 3 of the Table 4 shows that horizontal merger (HORI_MERGER) is positively related to the firm performance. We used the conglomerate merger in the Model 4, the results indicate that firm performed better when M\&A activity is a successful corporate diversification strategy.

Table 3: Linear Regression

\begin{tabular}{|c|c|c|c|c|}
\hline & Model 1 & Model 2 & Model 3 & Model 4 \\
\hline MERGER & $0.023 * * *$ & & & \\
\hline VER_MERGER & & 0.005 & & \\
\hline HORI_MERGER & & & $0.014 * * *$ & \\
\hline CONGLO_MERGER & & & & $0.007 *$ \\
\hline FSIZE & $-0.016 * * *$ & $-0.010 * * *$ & $-0.013 * * *$ & $-0.011 * * *$ \\
\hline INTER & -0.005 & -0.006 & -0.006 & -0.006 \\
\hline BUYERSTATUES & -0.004 & -0.006 & -0.005 & -0.005 \\
\hline IND BOARD & 0.019 & 0.018 & 0.018 & 0.018 \\
\hline CASH RATIO & $0.047 * * *$ & $0.046 * * *$ & $0.046 * * *$ & $0.045 * * *$ \\
\hline CONS & $0.147 * * *$ & $0.112 * * *$ & $0.128 * * *$ & $0.114 * * *$ \\
\hline R-Square & 0.0630 & 0.0634 & 0.0674 & 0.0639 \\
\hline F-Statistic & 32.04 & 24.97 & 27.94 & 25.48 \\
\hline $\mathrm{N}$ & 2604 & 2604 & 2604 & 2604 \\
\hline
\end{tabular}

\section{Discussion}

On the one hand, the results show that the general merger is beneficial to the combined entity after the M\&A activity and the hypothesis 1 is supported. Consistent with the findings of Jensen and Ruback (1983), Bhabra and Huang (2013), companies benefited from the synergy effects after two firms are combined into a single entity. 
However, our results do not provide sufficient evidence that the vertical merger affect the firm performance. Thus, the hypothesis 2 is not proven. The sample size of vertical mergers is too small, another possible explanation for that result is that the decrease in transaction costs cannot be reflected in the performance of the firm quickly. Most firms need to incur tremendous amount of corporate restructuring expenses immediately after M\&A.

We find that the horizontal merger is statistically positively related to the ROA and hence, the hypothesis 3 is supported. As documented by the studies of Han Kim and Singal (1993) and Fee and Thomas (2004), horizontal mergers companies can achieve economies of scale or increase market power and hence, perform better than after M\&A activity. Probably due to expansion of the market through economies of scale, this could help to enhance operational performance of the firm.

We report that the conglomerate merger improves firm performance and hence, the hypothesis 4 is supported. Similar to the findings by Elgers and Clark (2010) and Wansley et al. (2012), a firm can perform better after the M\&A activity as a result of the financial synergies. Moreover, obtaining businesses of different industries can help to diversify risks of the firm.

The result shows that control variable FSIZE, an indicator for the size of the acquirer's assets, is statistically significant negative, listed companies with relatively small scales have better performance. The possible reasons are when the enterprise scale is large, the integration process is jumbled, and the integration efficiency is low. The control variable CASH RATIO, percent of total assets held as cash, is statistically positively related to acquisition performance, show that companies with a high cash ratio can achieve better performance. This could be due to sufficient cash flow is more conducive to the rapid integration of enterprises

\section{Conclusion and Recommendations}

We provide evidence that M\&A activities are beneficial to Chinese listed companies after general merger, horizontal merger and conglomerate merger. This study fills the research gap on M\&A despite the rapid increases in both numbers and scale of such activities in the last ten years. This study not only contributes to enrich the literature on M\&A for Chinese listed companies, it also generates some suggestions for corporate decision makers.

There are certain limitations in this study. First of all, we have only studied publicly listed companies that account only a small number of firms, lots of M\&A occur for no-listed companies, which don't have mandatory requirements for information disclosures. It's recommended that long-term tracking of M\&A enterprises should be done in future research. Additionally, the industrial effect could be controlled better in future studies. In several industries, it appears that the frequencies of M\&A are high (energy, machine tools, automobiles, electronic products). We can continue our pursuit to have a better understanding of this important issue.

\section{References}

Asquith, P., Bruner, R. F., \& Mullins, D. W. (1983). The gains to bidding firms from merger. Journal of Financial Economics, 11(1-4), 121-139.

Bhabra, H. S., \& Huang, J. (2013). An empirical investigation of mergers and acquisitions by Chinese listed companies, 1997-2007. Journal of Multinational Financial Management, 23(3), 186-207. 
Bhattacharyya, S., \& Nain, A. (2011). Horizontal acquisitions and buying power: A product market analysis. Journal of Financial Economics, 99(1), 97-115.

Changqi, W., \& Ningling, X. (2010). Determinants of cross-border merger \& acquisition performance of Chinese enterprises. Procedia - Social and Behavioral Sciences, 2(5), 6896-6905.

Chen, G., Firth, M., \& Xu, L. (2009). Does the type of ownership control matter? Evidence from China's listed companies. Journal of Banking and Finance, 33(1), 171-181.

Chen, P., Xu, H., \& Zou, X. (2017). The effects and incentive of vertical mergers: An analysis from the view of OM. European Journal of Operational Research, 263(1), $158-172$.

Chen, Y. Y., \& Young, M. N. (2010). Cross-border mergers and acquisitions by Chinese listed companies: A principal-principal perspective. Asia Pacific Journal of Management, 27(3), 523-539.

Coase, R. H. (1934). The Nature of the Firm. Economics, 4(440), 440-446.

Company, P., Jensen, C., \& Meckling, H. (1976). THEORY OF THE FIRM : MANAGERIAL BEHAVIOR , AGENCY COSTS AND OWNERSHIP STRUCTURE. Journal of Financial Economics, 3, 305-360.

Dodd, P., \& Ruback, R. (1977). Tender offers and stockholder returns. An empirical analysis. Journal of Financial Economics, 5(3), 351-373.

Elgers, P. T., \& Clark, J. J. (2010). Additional Shareholder Returns : Evidence. Financial Management Association International, 9(2), 66-72.

Fan, J. P. H., \& Goyal, V. K. (2006). On the Patterns and Wealth Effects of Vertical Mergers*. Journal of Business, 79(2), 877-902.

Fee, C. E., \& Thomas, S. (2004). Sources of gains in horizontal mergers: Evidence from customer, supplier, and rival firms. Journal of Financial Economics, 74(3), 423-460.

Fraser, D. R., \& Zhang, H. (2009). Mergers and long-term corporate performance: Evidence from cross-border bank acquisitions. Journal of Money, Credit and Banking, 41(7), $1503-1513$.

Fu, X., Xiong, H., Li, J., \& Chesbrough, H. (2014). Open innovation as a response to constrains and risks and the moderating role of ownership. Asian Economic Papers, 13(3), 30-58.

Garcia-castro, R., Arin, M. A., \& Canela, M. A. (2010). Does Social Performance Really Lead to Financial Performance? Accounting for Endogeneity. Journal of Business Ethics, 107-126.

Ghosh, A. (2001). Does operating performance really improve following corporate acquisitions? Journal of Corporate Finance, 7(2), 151-178.

Han Kim, E., \& Singal, V. (1993). Mergers ans Market Power: Evidence from the Airline Industry. The American Economic Review, 83(3), 549-569.

Healy, P. M., Palepu, K. G., \& Ruback, R. S. (1990). DOES CORPORATE PERFORMANCE IMPROVE AFTER MERGERS?(No. w3348). Journal of Financial Economics, 31, 3149-3190.

Hu, B. J. (2018). Chinese Companies’ M\&A. Economy, 20-21.

Igor Ansoff. (1985). Conceptual underpinnings of systematic strategic management *. European Journal of Operational Research, 19(1), 2-19.

Jensen, M. C., \& Ruback, R. S. (1983). The Market for Corporate Control. Journal of Financial Economics, 11(1-4), 5-50. https://doi.org/10.1016/0304-405X(83)90004-1

Kelly, E. M. (1968). The profitability of growth through mergers. Journal of Finance, 23(3), $546-547$. 
Kruse, T. A., Park, H. Y., Park, K., \& Suzuki, K. (2007). Long-term performance following mergers of Japanese companies: The effect of diversification and affiliation. Pacific Basin Finance Journal, 15(2), 154-172.

Lang, L. H. P., \& Stulz, R. M. (1994). Tobin's q, Corporate Diversification, and Firm Performance. Ohio State University and National Bureau of Economic Researc, 102(6).

Leeth, J. D., Borg, J. R., The, S., Analysis, Q., Jun, N., Leeth, J. D., \& Borg, J. R. (2000). The Impact of Takeovers on Shareholder Wealth during the 1920s Merger Wave. Journal of Financial and Quantitative Analysis, 35(2), 217-238.

Liargovas, P., \& Repousis, S. (2011). The Impact of Mergers and Acquisitions on the Performance of the Greek Banking Sector: An Event Study Approach. International Journal of Economics and Finance, 3(2), 89-100.

Marfo, I., Samuel, O., \& Agyei, K. (2013). Mergers \& Acquisition and Firm Performance: Evidence from the Ghana Stock Exchange. Research Journal of Finance and Accounting, 4(7), 99-108.

Mei, B., \& Sun, C. (2008). Event analysis of the impact of mergers and acquisitions on the financial performance of the U.S. forest products industry. Forest Policy and Economics, 10(5), 286-294.

Mueller, D. C. (1967). A THEORY OF CONGLOMERATE MERGERS. National Bureau of Economic Research, 644-657.

Mueller, D. C. (2012). Mergers and the Market for Corporate Control. University of Chicago Press Terms and Conditions, 110-120.

Rahim, N. M., \& Pok, W. C. (2013). Shareholder wealth effects of M\&As: The third wave from Malaysia. International Journal of Managerial Finance, 9(1), 49-69.

Reviewed, M. L., Sociology, T., Simmel, G., Source, G. S., American, T., \& Review, E. (2009). American Economic Association. Philosophy, 40(2), 23-34.

Roll, R. (1986). The Hubris Hypothesis of Corporate Takeovers. The Journal of Business, 59(2), 197.

Schwert, G. W. (1996). Markup pricing in mergers and acquisitions. Journal of Financial Economics, 41(2), 153-192.

Servaes, H. (1996). The Value of Diversification During the Conglomerate Merger Wave. The Journal of Finance, LI(4), 1201-1225.

Va, G. B., \& Ofekb, E. (1995). Diversification's effect on $\mathrm{f}$ irm value. Journal of Financial Economics, 37, 39-65.

Wansley, J. W., Lane, W. R., \& Yang, H. C. (2012). Abnormal Returns to Acquired Firms by Type of Acquisition and Method of Payment. Financial Management, 12(3), 16-22.

Yeh, T., \& Hoshino, Y. (2002). Productivity and operating performance of Japanese merging firms: Keiretsu-related and independent mergers. Japan and the World Economy, 14(3), 347-366. 